Atıf İçin: Çöğender ME, Arslan NP, Aydoğan MN, 2021. Lokal olarak izole edilen fosfat çözücü Pseudomonas aeruginosa IBP26' nın nohut fidelerinin büyüme parametreleri üzerine etkisi. Iğdır Üniversitesi Fen Bilimleri Enstitüsü Dergisi, 11(2): 896-905.

To Cite: Çöğender ME, Arslan NP, Aydoğan MN, 2021. Effect of locally isolated phosphate-solubilizing Pseudomonas aeruginosa IBP26 on the growth parameters of chickpea seedling. Journal of the Institute of Science and Technology, 11(2): 896-905.

\title{
Effect of locally isolated phosphate-solubilizing Pseudomonas aeruginosa IBP26 on the growth parameters of chickpea seedling \\ Muhammed Emin ÇÖĞENDER ${ }^{1}$, Nazlı Pınar ARSLAN ${ }^{2}$, Mehmet Nuri AYDOĞAN ${ }^{1 *}$
}

\begin{abstract}
This work was conducted to examine the effect of locally isolated phosphate-solubilizing bacteria on the growth parameters of chickpea seedling cultivated in pots containing $\mathrm{Ca}_{3}\left(\mathrm{PO}_{4}\right)_{2}$ (tricalcium phosphate). Among the isolated strains, the highest phosphate-solubilizing activity in the broth medium was observed for the isolate IBP26. Similarly, in the greenhouse study, the same isolate was determined to cause maximum increases in growth parameters (shoot and root length, total biomass, phosphorus, total sugar, and protein contents) of chickpea plants in the presence of $\mathrm{Ca}_{3}\left(\mathrm{PO}_{4}\right)_{2}$. The isolate IBP26 was identified as Pseudomonas aeruginosa (GenBank accession number: MW092004). Experiments demonstrated that the application of the bacterium alone in the absence of $\mathrm{Ca}_{3}\left(\mathrm{PO}_{4}\right)_{2}$ or the application of $\mathrm{Ca}_{3}\left(\mathrm{PO}_{4}\right)_{2}$ alone in the absence of bacterium did not cause significant change in growth parameters of the chickpea plants, and that the desired increases in the growth parameters of these plants could be achieved by the co-application of bacterium and $\mathrm{Ca}_{3}\left(\mathrm{PO}_{4}\right)_{2}$.
\end{abstract}

Keywords: Pseudomonas aeruginosa IBP26, phosphate solubilization, chickpea, growth parameters.

\section{Lokal olarak izole edilen fosfat çözücü Pseudomonas aeruginosa IBP26' nın nohut fidelerinin büyüme parametreleri üzerine etkisi}

ÖZET: Bu çalışma, lokal olarak izole edilmiş fosfat çözücü bakterilerinin, $\mathrm{Ca}_{3}(\mathrm{PO} 4)_{2}$ (trikalsiyum fosfat) içeren saksılarda yetiştirilen nohut fidelerinin büyüme parametreleri üzerindeki etkisini incelemek için yapılmıştır. İzole edilen suşlar arasında, sıvı kültürde en yüksek fosfat çözündürücü aktivite IBP26 izolatı için gözlenmiştir. Benzer şekilde, sera çalışmasında da, aynı izolatın $\mathrm{Ca}_{3}\left(\mathrm{PO}_{4}\right)_{2}$ varlığında nohut bitkilerinin büyüme parametrelerinde (sürgün ve kök uzunluğu, biyokütle, fosfor, toplam şeker ve protein içeriği) maksimum artışa neden olduğu belirlenmiştir. IBP26 izolatı Pseudomonas aeruginosa olarak teşhis edilmiştir (GenBank accession number: MW092004). Deneyler, $\mathrm{Ca}_{3}\left(\mathrm{PO}_{4}\right)_{2}{ }^{\prime}$ nin yokluğunda tek başına bakteri uygulamasının veya bakteri yokluğunda tek başına $\mathrm{Ca}_{3}\left(\mathrm{PO}_{4}\right)_{2}$ uygulamasının nohut bitkilerinin büyüme parametrelerinde kayda değer değişime neden olmadığını, bu bitkilerinin büyüme parametrelerinde istenilen artışların bakteri ve $\mathrm{Ca}_{3}\left(\mathrm{PO}_{4}\right)_{2}{ }^{\prime}$ nin birlikte uygulanması sayesinde başarılabileceğini göstermiştir.

Anahtar Kelimeler: Pseudomonas aeruginosa IBP26, fosfat çözünürlüğü, nohut, büyüme parametreleri

\footnotetext{
${ }^{1}$ Muhammed Emin ÇÖĞENDER (Orcid ID: 0000-0003-1108-1240), Mehmet Nuri AYDOĞAN (Orcid ID: 0000-00017518-4746), Ataturk University, Science Faculty, Department of Biology, Erzurum, Turkey

${ }^{2}$ Nazlı Pınar ARSLAN (Orcid ID: 0000-0002-3951-4418), Bingol University, Vocational School of Health Services, Bingol, Turkey

*Sorumlu Yazar/Corresponding Author: Mehmet Nuri AYDOĞAN, e-mail: mnaydogan@ata.uni.edu.tr Bu çalışma Muhammed Emin ÇÖĞENDER'in Yüksek Lisans tezinden üretilmiştir.
} 


\section{INTRODUCTION}

Plant-associated bacteria can be classified into beneficial, deleterious and neutral groups based on their effects on plant growth. Beneficial bacteria are also known as plant growth promoting bacteria. They colonize the rhizosphere, the root surface, or the root itself. They may induce plant growth in two different ways, indirectly or directly (Rodríguez and Fraga, 1999; Vessey, 2003; Antoun and Prévost, 2005; Beneduzi et al., 2012). In indirect growth promotion, plant growth promoting bacteria reduce or prevent the harmful effect of pathogenic microorganisms by producing antibiotics or siderophores (Beneduzi et al., 2012; Olanrewaju et al., 2017). These bacteria promote directly plant growth through mechanisms such as the synthesis of phytohormones, $\mathrm{N}_{2}$ fixation, reduction of membrane potential of the roots, as well as the solubilization of inorganic phosphate and mineralization of organic phosphate (Rodríguez and Fraga, 1999; Amarasen et al., 2019).

Phosphorus is the second most important macro nutrient required by plants, after nitrogen. Therefore, application of phosphatic fertilizers is essential for higher crop yields in agricultural studies. However, phosphatic fertilizers become insoluble when applied to the soil and turn into complexes such as aluminum phosphate, calcium phosphate and iron phosphate in the soil (Walpola and Yoon, 2012). While the calcium form of insoluble phosphatic complexes is dominant in neutral to alkaline soil conditions, iron and aluminum phosphates are more dominant under acidic conditions. It has been documented that plants take up phosphorus as soluble orthophosphate ions $\left(\mathrm{H}_{2} \mathrm{PO}_{4}^{-1}\right.$ and $\left.\mathrm{HPO}_{4}{ }^{-2}\right)$, whereas the fixed form of phosphorus cannot be efficiently taken up by the plants (Kumar and Narula, 1999; Del Campillo et al., 1999).

Phosphate solubilizing microorganisms (PSMs) hydrolyze insoluble phosphatic compounds and make phosphorus more accessible for plants. Therefore, inoculation of soils with PSMs is known to result in higher crop yields (Johri et al., 1999; Walpola and Yoon, 2012; Kalayu, 2019; Hii et al., 2020). PSMs can solubilize phosphatic compounds by applying various mechanisms such as lowering soil $\mathrm{pH}$, chelation, and mineralization. Organic acids produced by microorganisms are effective in lowering soil pH (Kalayu, 2019). Namely, PSMs produce organic acids that lower of soil pH, thereby increasing phosphorus solubilization in the soil. There are many different organic acids that can dissolve phosphate and are produced by microorganisms; however, gluconic acid and 2-ketogluconic acids appear to be the most effective ones. PSMs include fungal (mainly Penicillium and Aspergillus strains), bacterial (mainly Bacillus, Pseudomonas and Rhizobium strains) and arbuscular mycorrhizal strains (Kalayu, 2019). Phosphate solubilizing bacteria may also enhance plant productivity by producing other secondary metabolites. The potential of phosphate-solubilizing bacteria to produce IAA and siderophore increases the potential of these bacteria to be used as bio fertilizers (Mamta et al., 2010). In the light of this knowledge, it is thought that phosphate dissolving bacteria will gain more importance in the future.

Herein, the present study was carried out to elucidate whether locally isolated phosphate solubilizing-bacteria had the potential to promote the growth of chickpea seedlings.

\section{MATERIALS AND METHODS}

\section{Isolation and screening of phosphate-solubilizing bacteria}

The soil sampes were collected from root zone and rhizosphere of various leguminous plants (wild chickpea and lentil) at different habitats in Erzurum province and its surrounding (Turkey). Nearly $1 \mathrm{~g}$ of soil samples was dispersed in $10 \mathrm{~mL}$ sterile-saline water. The prepared suspensions were separately vortexed and serially diluted up to $10^{-6}$ with sterile saline water. Then, $0.1 \mathrm{~mL}$ of each dilution sample was separately spread on 90-mm diameter petri dish containing $15 \mathrm{~mL}$ of NBRIP (National Botanical 
Research Institute's phosphate growth medium) medium. This medium composed of $\left(\mathrm{g} \mathrm{L}^{-1}\right) 10$ glucose, $5 \mathrm{Ca}_{3}\left(\mathrm{PO}_{4}\right)_{2}$ (tricalcium phosphate), $5 \mathrm{MgCl}_{2}, 0.25 \mathrm{MgSO}_{4}, 0.2 \mathrm{KCl}, 0.1\left(\mathrm{NH}_{4}\right)_{2} \mathrm{SO}_{4}$ and 20 agar-agar (pH 7.0). At the end of incubation period (2-4 days) at $30^{\circ} \mathrm{C}$, growing-bacterial colonies on the medium were sub-cultured and purified. The isolated strains were separately numbered and maintained at $4{ }^{\circ} \mathrm{C}$.

In the second step, the isolated strains were screened in terms of the potential to solubilize inorganic phospahete. For this purpose, $50 \mu \mathrm{L}$ seed culture (approximately $0.5-1 \times 10^{9} \mathrm{cfu} \mathrm{mL} \mathrm{m}^{-1}$ ) of each bacterial strain was separately transferred in the glass tubes containing $10 \mathrm{~mL}$ of sterilized NBRIP-BPB broth medium. Different from NBRIP, NBRIP-BPB contained $0.025 \mathrm{~g} \mathrm{~L}^{-1}$ bromphenol blue (BPB) as well as the other nutritional components but did not agar. Bacterium-free medium was used as control. The tubes were incubated at $30^{\circ} \mathrm{C}$ in a shaking incubator (New Brunswick Scientific, USA) at $180 \mathrm{rpm}$. At the end of 3days incubation period, tubes were centrifuged at $5000 \mathrm{rpm}$ for $10 \mathrm{~min}$. Absorbances of obtained supernatants were assayed at $600 \mathrm{~nm}$ using a spechtrophotometer (Mehta and Nautiyal, 2000). Soluble phosphate in culture supernatant was estimated by Vanadomolybdate method and expressed as equivalent phosphorus ( $\mathrm{mg} \mathrm{L}^{-1}$ ) (Jackson, 1973). Better phosphate-solubilizing isolates were selected and then used in the the next steps of the study.

\section{Bacterial inoculation and plant growth}

Chickpea seeds were surface sterilized with $1 \%$ sodium hypochlorite for $10 \mathrm{~min}$ and washed 4 times with sterilized distilled water. Afterwards, the seeds were soaked in distilled water about $24 \mathrm{~h}$ and were subjected to germination for 3 days. Twenty of germinated seeds were placed in each pot at $2 \mathrm{~cm}$ depth. Seedlings were grown for $10 \mathrm{~d}$ on pots containing sand. Each pot $(20 \mathrm{~cm}$ diameter) contained $2 \mathrm{~kg}$ of sand. Before using, sand was washed with water and then sterilized at $170^{\circ} \mathrm{C}$ for $60 \mathrm{~min}$. For inoculation, promising-strains were grown in NBRIP medium at $30^{\circ} \mathrm{C}$ for 3 days at $180 \mathrm{rpm}$. The optical density of obtained wet cells was adjusted to $10^{9}$ cells $/ \mathrm{mL}$ with saline water for each strain. One $\mathrm{mL}$ of suspension was inoculated on pots containing chickpea seeds.

The experimental design was consisted of four treatment as described follows - treatment 1: contained only sterilized sand and chickpea seeds (control 1); treatment 2: sterilized sand, insoluble phosphate and chickpea seeds (control 2); treatment 3: only sterilized sand, chickpea seeds and bacterium (control 3); treatment 4: sterilized sand, insoluble phosphate, chickpea seeds and bacteria. Pots were watered weekly with the nutrient solution described by Hoagland and Arnon (1950). But, this solution did not contain any phosphorus source apart from $5 \mathrm{~g} \mathrm{~L}^{-1} \mathrm{Ca}_{3}(\mathrm{PO} 4)_{2}$. Growth experiments were performed in a greenhouse (uncontrolled conditions).

\section{Determination of protein, reducing sugar and phosphorus contents as wel as shoot and root lengths}

Freshly harvested leaf samples $(0.5 \mathrm{~g})$ of chickpea plants were homogenized in $0.05 \mathrm{M}$ phosphate buffer ( $\mathrm{pH}$ 6.5). Homogenates were centrifuged at $15000 \mathrm{rpm}$ for $20 \mathrm{~min}$ at $4{ }^{\circ} \mathrm{C}$. Then, obtained supernatant was employed for the determination of protein amount (Bradford, 1976) and sugar contents (Miller 1959). Shoot and root lenghts were measured using a centrimeter scale. Phosphorus content was determined using an inductively coupled plasma optical emission spectrophotometer (Optima 2100 DV, Perkin-Elmer, Shelton, CT, USA).

\section{Identification of phosphate solubilizing bacteria}

The identification of the most promising isolate was performed according to whole-cell cellular fatty acids and $16 \mathrm{~S}$ rRNA analysis. Cellular fatty acids were analyzed by gas chromatography (GC) using the MIDI system (MIDI, Newark, DE). The analysis was performed using the Sherlock Microbial Identification system TSBA 4.0 software and library general system software version 4.1. Qualitative 
and quantitative differences in the fatty acid profiles were used to compute the distance for each strain relative to the strains in the library (Sasser, 1990a,b; Sasser and Wichman, 1991).

The identification of the isolate was also performed according to 16S rRNA sequence analysis. In brief, genomic DNA was extracted and purified according to the Promega Wizard ${ }^{\mathrm{R}}$ Genomic DNA Purification Kit (A2360) protocol. The purity of the extracted DNA was spectrophotometrically evaluated by A260/A280 ratio. The gene encoding for the $16 \mathrm{~S}$ rDNA was amplified by PCR using 27F (5'-AGAGTTTGATCCTGGCTCAG-3') and 1492R (5'-GGTTACCTTGTTACGACTT-3') universal bacterial primers. After the amplified fragments were cloned into Echerichia coli JM101 strain with the pGEM-T Easy Cloning Vector (Promega, Southampton, UK) according to the instructions of the manufacturer, the plasmid was purified using Wizard ${ }^{\circledR}$ Plus SV Minipreps DNA Purification System (Promega, A1330) kit and sequenced in Macrogen Company (Netherlands). The 16S rRNA obtained was compared with the other bacterial series in the GenBank and EzTaxon (http://blast.ncbi.nlm.nih and http://www.eztaxon.org), the similarity rate was determined and GenBank accession number was received.

\section{RESULTS AND DISCUSSION}

\section{Isolation and screening of phosphate-solubilizing bacteria}

Previous studies have widely demonstrated that phosphate-solubilizing bacterial inoculants improve plant growth and yield (Appanna, 2007; Hameeda et al., 2008; Vikram and Hamzehzarghani, 2008; Mohammed et al., 2011; Kalayu et al., 2019). Therefore, the present preliminary experiments were performed to isolate new bacterial strains being capable of solubilizing $\mathrm{Ca}_{3}(\mathrm{PO} 4)_{2}$, an insoluble inorganic phosphate. The isolation experiments were performed on NBRIP medium containing insoluble $\mathrm{Ca}_{3}\left(\mathrm{PO}_{4}\right)_{2}$ (tricalcium phosphate) as inorganic phosphate. Total 76 bacterial strains grown on this medium were picked up and purified. They were then screened on NBRIP-BPB (brom phenol) medium for the determination of better phosphate solubilizing-ones. Among 76 bacterial isolates, only five isolates were found to cause a significant decolorization in blue color of NBRIP-BPB medium, namely have high phosphate-solubizing activity. Phosphate-solubilizing potentials of five isolates (IPB 4, IPB 8, IPB 25, IPB 26 and IPB 72) were determined as 53.75, 52.47, 46.03, 110.86 and $27.58 \mathrm{mg} \mathrm{L}^{-1}$, respectively.

\section{Effect of phosphate-solubilizing bacteria on growth parameters of chickpea}

In the subsequent stages of the study, five isolates were evaluated in terms of the potential to promote the growth of chickpea in the presence of $\mathrm{Ca}_{3}\left(\mathrm{PO}_{4}\right)_{2}$. At the end of 10-days growth period, the plants were harvested and the average lengths of shoot and roots for each treatment group were recorded (Table 1). The experiments showed that no significant difference was observed between shoot lengths of treatment group 1 chickpea plants (plants grown on pots containing only sand) and treatment group 2 chickpea plants grown on pots containing sand and $\mathrm{Ca}_{3}(\mathrm{PO} 4)_{2}$. Similarly, no significant increase in shoot lengths of chickpea was detected, when chickpea seeds were grown on pots inoculated with bacteria (treatment group 3: sand, chickpea and bacterium). Whereas, the experiments exhibited that there was a significant increase in shoot length of the plants, which were grown in the presence of bacteria and $\mathrm{Ca}_{3}\left(\mathrm{PO}_{4}\right)_{2}$ (treatment group 4). Shoot lenghts of chickpea plants with inoculated IPB 4, IPB 8, IPB 25, IPB 26 and IPB 72 were determined as 21.83, 19.70, 18.20, 23.41 and $14.48 \mathrm{~cm}$, respectively (treatment group 4). Whereas, average shoot lenght of control plants (treatment group 1) was determined as 12.94 $\mathrm{cm}$. 

seedling

With comparison to treatment group 1 plants, there were no important changes in root lengths of treatment group 2 and 3 plants (Table 1). Even, shorter root lengths were assayed for treatment group 3 plants which were inoculated with any of four isolates (IPB 4, IPB 25, IPB 26 and IPB 72) in the absence of $\mathrm{Ca}_{3}\left(\mathrm{PO}_{4}\right)_{2}$. Conversely, longer root lengths were reached when chickpea seeds were grown in the presence of $\mathrm{Ca}_{3}\left(\mathrm{PO}_{4}\right)_{2}$ and test bacterium (Treatment group 4). Among treatment group 4 plants, the plants inoculated with IBP26 were found to have the maxium root length $(12.06 \mathrm{~cm})$. Whereas, average root length of treatment group 1 was assayed as only $7.50 \mathrm{~cm}$.

Table 1. Effect of test bacteria on shoot and root lengths of chickpea

\begin{tabular}{lcc}
\hline Treatment groups & Shoot length $(\mathbf{c m})$ & Root length $(\mathbf{c m})$ \\
\hline TG1(sand, chickpea seeds) & $12.94^{\mathrm{cd}}$ & $7.50^{\mathrm{c}}$ \\
TG2(sand, chickpea seeds, $\left.\mathrm{Ca}_{3}\left(\mathrm{PO}_{4}\right)_{2}\right)$ & $13.38^{\mathrm{cd}}$ & $7.70^{\mathrm{bc}}$ \\
TG3 (sand, chickpea seeds, IPB4) & $13.42^{\mathrm{cd}}$ & $7.02^{\mathrm{c}}$ \\
TG3 (sand, chickpea seeds, IPB8) & $11.89^{\mathrm{d}}$ & $8.08^{\mathrm{bc}}$ \\
TG3 (sand, chickpea seeds, IPB25) & $13.14^{\mathrm{cd}}$ & $7.45^{\mathrm{c}}$ \\
TG3 (sand, chickpea seeds, IPB26) & $13.41^{\mathrm{cd}}$ & $7.42^{\mathrm{c}}$ \\
TG3 (sand, chickpea seeds, IPB72) & $13.24^{\mathrm{cd}}$ & $7.03^{\mathrm{c}}$ \\
TG4 (sand, chickpea seeds, $\left.\mathrm{Ca}_{3}\left(\mathrm{PO}_{4}\right)_{2}, \mathrm{IPB} 4\right)$ & $21.83^{\mathrm{a}}$ & $11.31^{\mathrm{a}}$ \\
TG4 (sand, chickpea seeds, $\left.\mathrm{Ca}_{3}\left(\mathrm{PO}_{4}\right)_{2}, \mathrm{IPB} 8\right)$ & $19.70^{\mathrm{b}}$ & $9.23^{\mathrm{b}}$ \\
TG4 (sand, chickpea seeds, $\left.\mathrm{Ca}_{3}\left(\mathrm{PO}_{4}\right)_{2}, \mathrm{IPB} 25\right)$ & $18.20^{\mathrm{b}}$ & $10.83^{\mathrm{a}}$ \\
TG4 (sand, chickpea seeds, $\left.\mathrm{Ca}_{3}\left(\mathrm{PO}_{4}\right)_{2}, \mathrm{IPB} 26\right)$ & $23.41^{\mathrm{a}}$ & $12.06^{\mathrm{a}}$ \\
TG4 (sand, chickpea seeds, $\left.\mathrm{Ca}_{3}\left(\mathrm{PO}_{4}\right)_{2}, \mathrm{IPB} 72\right)$ & $14.48^{\mathrm{c}}$ & $8.53^{\mathrm{bc}}$ \\
\hline
\end{tabular}

All values are the mean of two replicates from three independent experiments $(n=6)$. Different lowercase letters in the same column indicate significant differences $(\mathrm{P}<0.05)$. TG: treatment group

As for the total sugar and protein contents of chickpea plants in four different treatment groups, it was seen that treatment group 4 chickpea plants had higher protein and sugar contents (Table 2). Especially, the highest total sugar (30.9 $\left.\mathrm{mg} \mathrm{g}^{-1}\right)$ and protein $\left(14.25 \mathrm{mg} \mathrm{g}^{-1}\right)$ contents were recorded for the chickpea plants inoculated with IBP-26 among the treatment group 4 plants. In parallel with shoot and root lengths, there was no significant decrease or increase in total sugar and protein contents of treatment group 2 and 3 plants compared to treatment group 1 plants.

Table 2. Effect of test bacteria on total sugar and protein contents of chickpea

\begin{tabular}{lcc}
\hline Treatment groups & Total sugar $\left(\mathbf{m g ~ g}^{-\mathbf{1}}\right)$ & Protein content $\left(\mathbf{m g ~ g}^{-\mathbf{1}}\right)$ \\
\hline TG1(sand, chickpea seeds) & $22.0^{\mathrm{f}}$ & $11.74^{\mathrm{de}}$ \\
TG2(sand, chickpea seeds, $\left.\mathrm{Ca}_{3}\left(\mathrm{PO}_{4}\right)_{2}\right)$ & $23.0^{\mathrm{ef}}$ & $11.55^{\mathrm{e}}$ \\
TG3 (sand, chickpea seeds, IPB4) & $24.2^{\mathrm{ef}}$ & $12.25^{\mathrm{cde}}$ \\
TG3 (sand, chickpea seeds, IPB8) & $25.2^{\mathrm{de}}$ & $11.6^{\mathrm{e}}$ \\
TG3 (sand, chickpea seeds, IPB25) & $25.2^{\mathrm{de}}$ & $12.2^{\text {cde }}$ \\
TG3 (sand, chickpea seeds, IPB26) & $25.5^{\mathrm{de}}$ & $12.75^{\mathrm{bcde}}$ \\
TG3 (sand, chickpea seeds, IPB72) & $22.5^{\mathrm{de}}$ & $11.90^{\mathrm{cde}}$ \\
TG4 (sand, chickpea seeds, $\left.\mathrm{Ca}_{3}\left(\mathrm{PO}_{4}\right)_{2}, \mathrm{IPB} 4\right)$ & $30.9^{\mathrm{ab}}$ & $13.89^{\mathrm{ab}}$ \\
TG4 (sand, chickpea seeds, $\left.\mathrm{Ca}_{3}\left(\mathrm{PO}_{4}\right)_{2}, \mathrm{IPB} 8\right)$ & $27.5^{\mathrm{cd}}$ & $12.95^{\mathrm{bcd}}$ \\
TG4 (sand, chickpea seeds, $\left.\mathrm{Ca}_{3}\left(\mathrm{PO}_{4}\right)_{2}, \mathrm{IPB} 25\right)$ & $28.2^{\mathrm{bc}}$ & $13.0^{\mathrm{bc}}$ \\
TG4 (sand, chickpea seeds, $\left.\mathrm{Ca}_{3}\left(\mathrm{PO}_{4}\right)_{2}, \mathrm{PPB} 26\right)$ & $30.9^{\mathrm{a}}$ & $14.25^{\mathrm{a}}$ \\
TG4 (sand, chickpea seeds, $\left.\mathrm{Ca}_{3}\left(\mathrm{PO}_{4}\right)_{2}, \mathrm{IPB} 72\right)$ & $26.9^{\mathrm{cd}}$ & $12.75^{\mathrm{bcde}}$ \\
\hline
\end{tabular}

All values are the mean of two replicates from three independent experiments $(n=6)$. Different lowercase letters in the same column indicate significant differences $(\mathrm{P}<0.05)$. TG: treatment group 
The experiments demonstrated that supplementation of $\mathrm{Ca}_{3}\left(\mathrm{PO}_{4}\right)_{2}$ had not a significant role on $\mathrm{P}$ content in the absence of the test bacteria. In the other words, no significant increase occurred in $\mathrm{P}$ content of treatment group 2 plants compared with treatment group 1 plants (Table 3). The maximum augmentation in $\mathrm{P}$ uptake by plants was achieved, when the plants were grown in the presence of test bacteria and $\mathrm{Ca}_{3}\left(\mathrm{PO}_{4}\right)_{2}$ (treatment group 4 plants). Among the treatment group 4 plants, the maximum $\mathrm{P}$ content $\left(2671 \mathrm{mg} \mathrm{kg}^{-1}\right)$ was determined in chickpea plants with inoculated with IBP-26. Similarly, higher dry matter contents were assayed for the plants, which were inoculated with the test bacteria in the presence of $\mathrm{Ca}_{3}\left(\mathrm{PO}_{4}\right)_{2}$. Especially, the maximum dry matter content $(22.2 \%)$ was detected for the plants inoculated with IBP 26 among treatment group 4 plants (Table 3).

Table 3. Effect of test bacteria on dry matter and phosphorus contents of chickpea

\begin{tabular}{lcc}
\hline Treatment groups & Dry matter $(\%)$ & Phosphorus content $\left(\mathbf{m g ~ k g}^{-\mathbf{1}}\right)$ \\
\hline TG1(sand, chickpea seeds) & $17.41^{\mathrm{d}}$ & 2114 \\
TG2(sand, chickpea seeds, $\left.\mathrm{Ca}_{3}\left(\mathrm{PO}_{4}\right)_{2}\right)$ & $19.21^{\mathrm{bcd}}$ & 2177 \\
TG3 (sand, chickpea seeds, IPB4) & $18.89^{\mathrm{bcd}}$ & 2415 \\
TG3 (sand, chickpea seeds, IPB8) & $19.40^{\mathrm{bcd}}$ & 2347 \\
TG3 (sand, chickpea seeds, IPB25) & $19.56^{\mathrm{bcd}}$ & 2249 \\
TG3 (sand, chickpea seeds, IPB26) & $17.55^{\mathrm{d}}$ & 2367 \\
TG3 (sand, chickpea seeds, IPB72) & $19.21^{\mathrm{bcd}}$ & 2415 \\
TG4 (sand, chickpea seeds, $\mathrm{Ca}_{3}\left(\mathrm{PO}_{4}\right)_{2}$, IPB4) & $21.46^{\mathrm{ab}}$ & 2623 \\
TG4 (sand, chickpea seeds, $\left.\mathrm{Ca}_{3}\left(\mathrm{PO}_{4}\right)_{2}, \mathrm{IPB} 8\right)$ & $20.69^{\mathrm{abc}}$ & 2510 \\
TG4 (sand, chickpea seeds, $\left.\mathrm{Ca}_{3}\left(\mathrm{PO}_{4}\right)_{2}, \mathrm{IPB} 25\right)$ & $21.10^{\mathrm{abc}}$ & 2369 \\
TG4 (sand, chickpea seeds, $\left.\mathrm{Ca}_{3}\left(\mathrm{PO}_{4}\right)_{2}, \mathrm{IPB} 26\right)$ & $22.29^{\mathrm{a}}$ & 2671 \\
TG4 (sand, chickpea seeds, $\left.\mathrm{Ca}_{3}\left(\mathrm{PO}_{4}\right)_{2}, \mathrm{IPB} 72\right)$ & $19.76^{\mathrm{abcd}}$ & 2227 \\
\hline
\end{tabular}

All values are the mean of two replicates from three independent experiments $(n=6)$. Different lowercase letters in the same column indicate significant differences $(\mathrm{P}<0.05)$. TG: treatment group

As seen from the results presented in Table 1-3, compared to the control (treatment group 1), test bacteria (treatment group 3) alone or $\mathrm{Ca}_{3}\left(\mathrm{PO}_{4}\right)_{2}$ (treatment group 2) alone did not cause a significant change in plant growth parameters (shoot and root lengths, total sugar, protein and dry matter contents). The absence of any change in the treatment group 2 plants can be explained by the fact that insoluble $\mathrm{Ca}_{3}\left(\mathrm{PO}_{4}\right)_{2}$ is not directly used as phosphorus source by the plants. Conversely, it was seen that the growth of chickpea plants significantly increased, when the plants were inoculated with phosphate-solubilizing test bacteria in the presence of $\mathrm{Ca}_{3}\left(\mathrm{PO}_{4}\right)_{2}$. Namely, co-application of any test bacterium and $\mathrm{Ca}_{3}\left(\mathrm{PO}_{4}\right)_{2}$ caused a significant increase in growth of chickpea seedlings (treatment group 4). Significant increases in growth parameters can mainly be attributed to greater $\mathrm{P}$ uptake by the plants. This is because, the present experiments revealed that the maximum $\mathrm{P}$ content was detected in the plants which were grown in the presence of test bacteria and $\mathrm{Ca}_{3}\left(\mathrm{PO}_{4}\right)_{2}$ (treatment group 4 plants). The similar increases in $\mathrm{P}$ uptake in the presence of phosphate solubilizing bacteria have been also reported for other plants such as Phaseolus vulgaris, Lycopersicon esculentum and Stevia rebaudiana in the previous studies (Peix et al., 2001; Han and Lee, 2005; Kirankumar et al., 2008; Rahi et al., 2010; Mohamed et al., 2011; Kuntyastuti and Sutrisno, 2017).

From all the results obtained, it was clear that the maximum increases in shoot and root lengths as well as total sugar, protein, dry matter and phosphorus contents were achieved with the isolate IPB 26. This isolate was identified as Pseudomonas aeruginosa according to morphological and biochemical characteristics as well as FAME and 16S rRNA analyses (GenBank accession number: MW092004). This result was in good agreement with those reported by investigators, which showed that Pseudomonas 
strains possesed high potential to promote growth of different plants (Buch et al., 2008; Ahemad and Khan, 2010; Patel et al., 2011; Prasad and Babu, 2017). Therefore, use of P. aeruginosa IPB26 as biofertilizers can be accepted as an efficient approach to replace chemical phosphorus fertilizers for sustainable cultivation of chickpea plants.

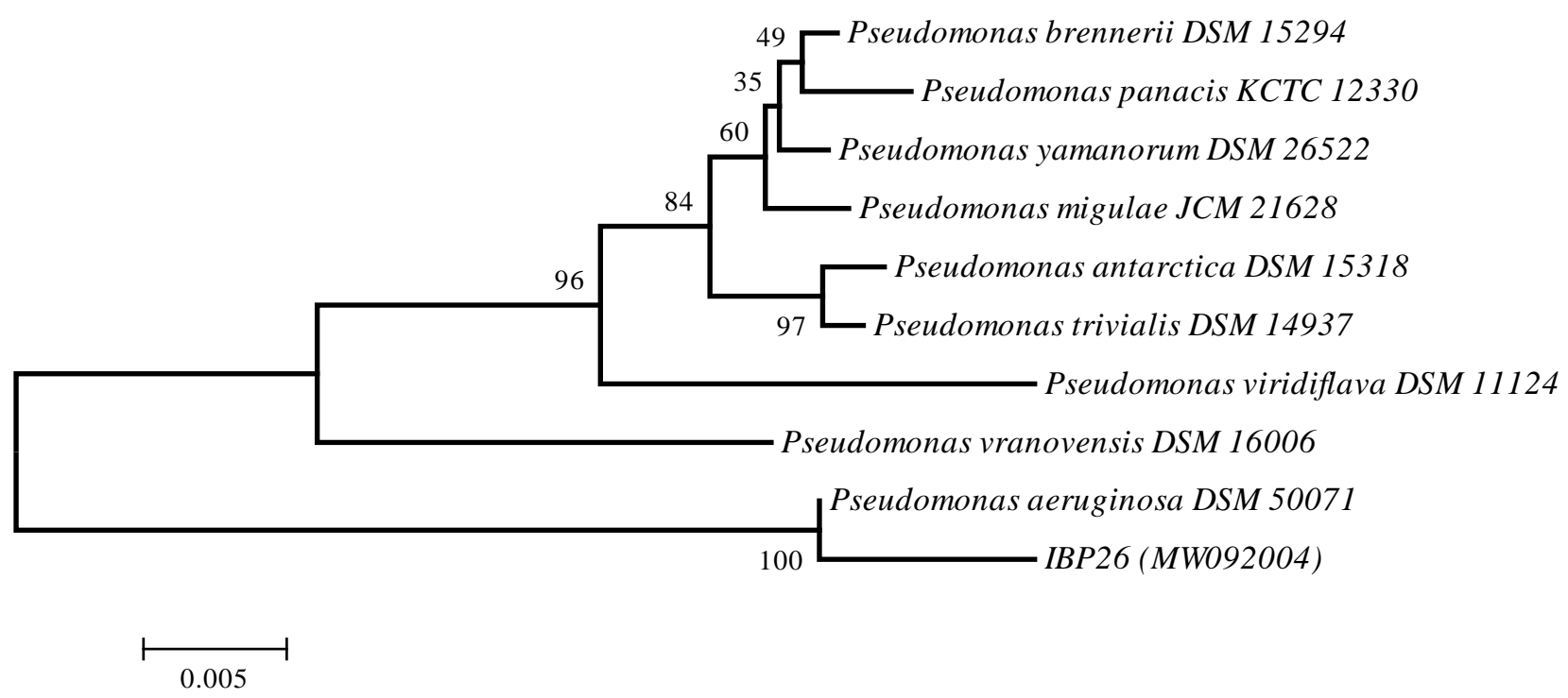

Figure 1. Neighbor joining phylogenetic tree on the basis of 16S rRNA gene sequence data of the isolate IBP26 (GenBank number: MW092004) resembled Pseudomonas aeruginosa at a high rate (98.5\%).

It has been reported in the literature that plant growth promoting rhizobacteria (PGPR) may have other potential properties such as the synthesis of phytohormones, $\mathrm{N}_{2}$ fixation and being biocontrol agent, in addidion to the solubilization of inorganic phosphate and mineralization of organic phosphate (Almas et al., 2009; Hayat et al., 2012; Öztekin et al., 2015; Şahin and Dönmez, 2020). For example, several authors have informed that PGPR are capable of producing phytohormones such as indole-3acetic acid, cytokinin and gibberellin promoting plant growth (Mehnaz et al., 2001; van Loon et al., 2007; Gupta et al., 2012; Patel and Saraf 2017). Considering this information, the fact that there is no change in the growth parameters of the treatment group 3 plants can be explained by the failure of test bacteria to produce phytohormones or to fix nitrogen. That is, the test bacteria had probably only phosphate solubilizing potential. However, we consider that co-culture of $P$. aeruginosa IPB26 and other plant growth promoting bacteria (nitrogene-fixing and/or phytohormone-producing bacteria) may be tested in future agricultural studies. This is because, the co-application of phosphate-solubilizing bacteria with nitrogene-fixing and/or phytohormone-producing other PGPR is accepted as an alternative approach in agricultural studies. Even, co-cultures provide more balanced compared with separate inoculations (Rodríguez and Fraga, 1999). For example, when phosphate-solubilizing Agrobacterium radiobacter was combined with nitrogen fixer Azospirillum lipoferum, more improvement in grain yield of barley could be achieved compared with single inoculations (Belimov et al., 1995).

\section{CONCLUSION}

This study revealed that application of $P$. aeruginosa IPB26 in the presence of $\mathrm{Ca}_{3} \mathrm{PO}_{4}$ gave rise to significant increases in the growth parameters of chickpea plants. Therefore, use of $P$. aeruginosa IPB26 as biofertilizers can be accepted as an efficient approach to replace chemical phosphorus fertilizers for sustainable cultivation of chickpea plants. 


\section{Conflict of Interest}

The authors declare that they have no conflict of interest.

\section{Author's Contibutions}

The experiments as regarding the effect of the test bacterium on the plant growth parameters were performed by Muhammed Emin ÇÖĞENDER. Molecular identification of the bacterium was carried out by Nazlı Pınar ARSLAN. Mehmet Nuri AYDOĞAN was responsible for the writing of manuscript.

\section{REFERENCES}

Ahemad M, Khan MS, 2010. Phosphate-Solubilizing and Plant-Growth-Promoting Pseudomonas aeruginosa PS1 Improves Greengram Performance in Quizalafop-p-ethyl and Clodinafop Amended Soil. Archives of Environmental Contamination and Toxicology, 58:362-372.

Almas Z, Mohammad SK, Munees A, Mohd O, Wani PA, 2009. Recent advances in plant growth promotion by phosphate-solubilizing microbes. In Mohammad, S. K., Almas, Z. and Javed, M. (eds.) Microbial Strategies for Crop Improvement. Springer, Verlag Berlin Heidelberg. pp. 23-49.

Amaresan N, Jayakumar V, Kumar K, Thajuddin N, 2019. Biocontrol and plant growth-promoting ability of plantassociated bacteria from tomato (Lycopersicum esculentum) under field condition. Microbial Pathogenesis, 136:103713.

Antoun H, Prévost D. 2005. Ecology of plant growthpromoting rhizobacteria. Z. A. Siddiqui (ed.), PGPR: Biocontrol and Biofertilization 1-38.

Appanna V, 2007. Efficacy of phosphate solubilizing bacteria isolated from vertisols on growth and yield parameters of sorghum. Research Journal of Microbiology, 2:550-559.

Bradford MM, 1976. A rapid and sensitive method for $t$ quantition of microgram quantities of protein utilising the princible of protein-dye binding analitic. Biochemistry, 72:248-254.

Belimov AA, Kojemiakov AP, Chuvarliyeva CV, 1995. Interaction between barley and mixed cultures of nitrogen fixing and phosphate-solubilizing bacteria. Plant and Soil 173:29-37.

Beneduzi A, Ambrosini A, Passaglia LM, 2012. Plant growth-promoting rhizobacteria (PGPR): their potential as antagonists and biocontrol agents. Genetics and Molecular Biology, 35:1044-1051.

Buch A, Archana G, Naresh KG, 2008. Metabolic channeling of glucose towards gluconate in phosphatesolubilizing Pseudomonas aeruginosa P4 under phosphorus deficiency. Research in Microbiology, 159:653-642.

Del Campillo SE, Van der Zee S, Torrent J, 1999. Modelling long term phosphorus leaching and changes in phosphorus fertility in excessively fertilized acid sandy soils. European Journal of Soil Science, 50:391399.

Gupta M, Kiran S, Gulati A, Singh B, Tewari R, 2012. Isolation and identification of phosphate solubilizing bacteria able to enhance the growth and aloin-A biosynthesis of Aloe barbadensis Miller. Microbiological Research, 167:358-363.

Hameeda B, Harini G, Rupela OP, Wani SP, Reddy G, 2008. Growth promotion of maize by phosphate solubilizing bacteria isolated from composts and macrofauna. Microbiological Research, 163:234-242.

Han HS, Lee KD, 2005. Physiological responses of soybean-inoculation of Bradyrhizobium japonicum with PGPR in saline soil conditions. Research Journal of Agriculture and Biological Sciences, 1:216-221.

Hayat R, Ahmed I, Sheirdil RA, 2012. An overview of plant growth promoting rhizobacteria (PGPR) for sustainable agriculture. In Crop production for agricultural improvement (pp. 557-579). Springer, Dordrecht.

Hii YS, San Chan Y, Lau SW, Michael D, 2020. Isolation and characterisation of phosphate solubilizing microorganisms from peat. Biocatalysis and Agricultural Biotechnology, 26:101643.

Jackson ML 1973. Soil Chemical Analysis. Prentice Hall of India Private Limited New Delhi, 38-82. 
Johri JK, Surange S, Nautiyal CS, 1999. Occurrence of salt, ph, and temperature-tolerant, phosphate-solubilizing bacteria in alkaline soils. Current Microbiology, 39:89-93.

Kalayu G, 2019. Phosphate solubilizing microorganisms: promising approach as biofertilizers. International Journal of Agronomy, 2019:1-7.

Kirankumar R, Jagadeesh KS, Krishnaraj PU, Patil MS, 2008. Enhanced growth promotion of tomato and nutrient uptake by plant growth promoting rhizobacterial isolates in presence of tobacco mosaic virus pathogen. Karnataka Journal of Agricultural Sciences, 21:309-311.

Kumar V, Narula N, 1999. Solubilization of inorganic phosphates and growth emergence of wheat as affected by Azotobacter chroococcum mutants. Biology and Fertility of Soils $28: 301-305$.

Kuntyastuti H, Sutrisno S, 2017. Effect of manure, phosphate solubilizing bacteria, and chemical fertilizer application on the growth and yield of soybean. Nusantara Bioscience, 9:126-132.

Mamta RP, Pathania V, Gulati A, Singh B, Bhanwra RK, Tewari R, 2010. Stimulatory effect of phosphatesolubilizing bacteria on plant growth, stevioside and rebaudioside-A contents of Stevia rebaudiana Bertoni. Applied Soil Ecology 46:222-229.

Mehnaz S, Mirza MS, Haurat J, Bally R, Normand P, Bano A, Malik KA, 2001. Isolation and 16S rRNA sequence analysis of the beneficial bacteria from the rhizosphere of rice. Canadian Journal of Microbiology, 472:110117.

Mehta S, Nautiyal CS, 2000. An efficient method for qualitative screening of phosphate- solubilizing bacteria. Current Microbiology 43: 51-56.

Miller GL, 1959. Use of dinitosalicylic acid reagent for the determination of reducing sugar. Analytical Chemistry 31:426-428.

Mohamed, HM, Ibrahim EMA, 2011. Effect of inoculation with Bacillus polymyxa mutants on growth, phosphorous and iron uptake by tomato (Lycopersicon esculentum L.) in calcareous soils. International Journal of Soil Science, 6:176-187.

Olanrewaju OS, Glick BR, Babalola OO, 2017. Mechanisms of action of plant growth promoting bacteria. World Journal of Microbiology and Biotechnology, 33:197.

Öztekin GB, Tuzel Y, Mehmet E, 2015. Effect of nitrojen fixing bacteria use on plant growth, yield and fruit quality of tomatoes grown in greenhouse conditions. Igdır University Journal of the institute of Science and Technology, 5:21-27.

Patel DK, Murawala P, Archana G, Kumar GN, 2011. Repression of mineral phosphate solubilizing phenotype in the presence of weak organic acids in plant growth promoting fluorescent pseudomonads. Bioresource Technology, 102:3055-3061.

Patel T, Saraf M, 2017. Biosynthesis of phytohormones from novel rhizobacterial isolates and their in vitro plant growth-promoting efficacy. Journal of Plant Interactions, 12:480-487.

Peix A, Mateos PF, Rodriguez-Barrueco C, Martinez-Molina E, Velazquez E, 2001. Growth promotion of common bean (Phaseolus vulgaris L.) by a strain of Burkholderia cepacia under growth chamber conditions. Soil Biology and Biochemistry, 33:1927-1935.

Prasad AA, Babu S, 2017. Compatibility of Azospirillum brasilense and Pseudomonas fluorescens in growth promotion of groundnut (Arachis hypogea L.). Anais da Academia Brasileira de Ciências, 89:1027-1040.

Rahi MP, Pathania V, Gulati A, Singh B, Bhanwra RK, Tewari R, 2010. Stimulatory effect of phosphatesolubilizing bacteria on plant growth, stevioside and rebaudioside-A contents of Stevia rebaudiana Bertoni. Applied Soil Ecology, 46: 222-229.

Rodríguez H, Fraga R, 1999. Phosphate solubilizing bacteria and their role in plant growth promotion. Biotechnology Advances 17:319-339.

Sasser M, 1990a. Technical Note 102. Tracking a Strain Using the Microbial Identification System. MIS, Newark, DE.

Sasser M, 1990b. Identification of bacteria through fatty acid analysis. In: Klement, Z., Rudolph, K., Sands, D. (Eds.), Methods in Phytobacteriology. Akademiai Kiado, Budapest, Hungary, pp. 199-204. 
Sasser M, Wichman MD, 1991. Identification of microorganisms through use of gas chromatography and highperformance liquid chromatography. In: Balows, A., Hausler Jr., W.J., Herrman, K.L., Isenberg, H.D., Shadomy, H.J. (Eds.), Manual of Clinical Microbiology, fifth ed. American Society for Microbiology, Washington, DC.

Şahin BU, Dönmez MF, 2020. Effects of different bacteria applications on tomato (Solanum lycopersicum L.) plant growth. Igdır University Journal of the institute of Science and Technology, 10:1507-1517

van Loon LC, 2007. Plant responses to plant growth-promoting rhizobacteria. European Journal of Plant Pathology, 119:243-254.

Vessey JK, 2003. Plant growth promoting rhizobacteria as biofertilizers. Plant Soil 255: 571-586.

Vikram A, Hamzehzarghani H, 2008. Effect of phosphate solubilizing bacteria on nodulation and growth parameters of greengram (Vigna radiata L. Wilczek). Research Journal of Microbiology, 3: 62-72.

Walpola BC, Yoon MH, 2012. Prospectus of phosphate solubilizing microorganisms and phosphorus availability in agricultural soils: A review. African Journal of Microbiology Research, 6:6600-6605. 